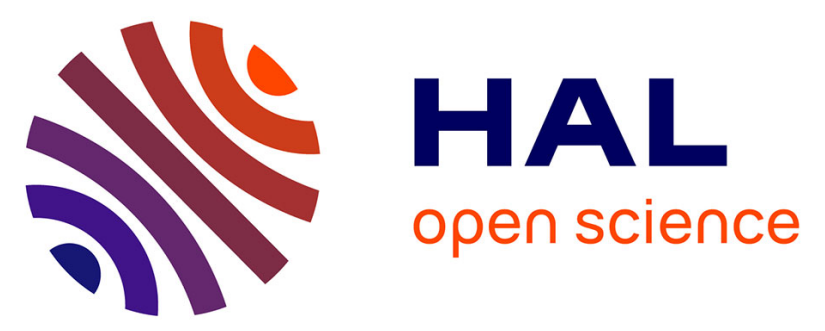

\title{
A network of water vapor Raman lidars for improving heavy precipitation forecasting in southern France: introducing the WaLiNeAs initiative
}

Cyrille Flamant, Patrick Chazette, Olivier Caumont, Paolo Di Girolamo, Andreas Behrendt, Michaël Sicard, Julien Totems, Diego Lange, Nadia Fourrié, Pierre Brousseau, et al.

\section{To cite this version:}

Cyrille Flamant, Patrick Chazette, Olivier Caumont, Paolo Di Girolamo, Andreas Behrendt, et al.. A network of water vapor Raman lidars for improving heavy precipitation forecasting in southern France: introducing the WaLiNeAs initiative. Bulletin of Atmospheric Science and Technology, 2021, 2 (1-4), pp.10. 10.1007/s42865-021-00037-6 . insu-03355725

\section{HAL Id: insu-03355725 \\ https://hal-insu.archives-ouvertes.fr/insu-03355725}

Submitted on 27 Sep 2021

HAL is a multi-disciplinary open access archive for the deposit and dissemination of scientific research documents, whether they are published or not. The documents may come from teaching and research institutions in France or abroad, or from public or private research centers.
L'archive ouverte pluridisciplinaire HAL, est destinée au dépôt et à la diffusion de documents scientifiques de niveau recherche, publiés ou non, émanant des établissements d'enseignement et de recherche français ou étrangers, des laboratoires publics ou privés. 


\title{
A network of water vapor Raman lidars for improving heavy precipitation forecasting in southern France: introducing the WaLiNeAs initiative
}

\author{
Cyrille Flamant $^{1}$ (D) Patrick Chazette ${ }^{2}$. Olivier Caumont ${ }^{3}$ - Paolo Di Girolamo ${ }^{4}$. \\ Andreas Behrendt ${ }^{5}$. Michaël Sicard ${ }^{6,7}$. Julien Totems ${ }^{2}$. Diego Lange ${ }^{5}$. \\ Nadia Fourrié ${ }^{3}$. Pierre Brousseau ${ }^{3}$. Clotilde Augros ${ }^{3} \cdot$ Alexandre Baron $^{2}$. \\ Marco Cacciani ${ }^{4}$. Adolfo Comerón ${ }^{6}$ - Benedetto De Rosa ${ }^{4} \cdot$ Veronique Ducrocq $^{3}$. \\ Pascal Genau ${ }^{1}$. Laurent Labatut ${ }^{3}$. Constantino Muñoz-Porcar ${ }^{6}$. \\ Alejandro Rodríguez-Gómez ${ }^{6} \cdot$ Donato Summa $^{4,8} \cdot$ Rohith Thundathil $^{5}$. \\ Volker Wulfmeyer ${ }^{5}$
}

Received: 8 March 2021 / Accepted: 26 May 2021

(c) The Author(s), under exclusive licence to Springer Nature Switzerland AG 2021

\begin{abstract}
Extreme heavy precipitation events (HPEs) pose a threat to human life but remain difficult to predict because of the lack of adequate high frequency and high-resolution water vapor (WV) observations in the low troposphere (below $3 \mathrm{~km}$ ). To fill this observational gap, we aim at implementing an integrated prediction tool, coupling network measurements of WV profiles, and a numerical weather prediction model to precisely estimate the amount, timing, and location of rainfall associated with HPEs in southern France (struck by $\sim 7$ HPEs per year on average during the fall). The Water vapor Lidar Network Assimilation (WaLiNeAs) project will deploy a network of 6 autonomous Raman WV lidars around the Western Mediterranean to provide measurements with high vertical resolution and accuracy to be assimilated in the French Application of Research to Operations at Mesoscale (AROME-France) model, using a four-dimensional ensemble-variational approach with 15-min updates. This integrated prediction tool is expected to enhance the model capability for kilometer-scale prediction of HPEs over southern France up to $48 \mathrm{~h}$ in advance. The field campaign is scheduled to start early September 2022, to cover the period most propitious to heavy precipitation events in southern France. The Raman WV lidar network will be operated by a consortium of French, German, Italian, and Spanish research groups. This project will lead to recommendations on the lidar data processing for future operational exploitation in numerical weather prediction (NWP) systems.
\end{abstract}

Keywords Remote sensing · Numerical weather prediction model · AROME · Assimilation · Western Mediterranean

Cyrille Flamant

cyrille.flamant@latmos.ipsl.fr

Extended author information available on the last page of the article 


\section{Introduction}

Heavy precipitation events (HPEs) pose a threat to human lives (e.g., Llasat et al. 2013) as well as the economy and the environment of impacted regions. HPEs occurring in small and steep watersheds are responsible for the triggering of flash floods with a sudden and often violent onset and rapid rise of rivers, typically from 1 to $6 \mathrm{~h}$ following the causative rainfall (Gaume et al. 2009). Flash floods and landslides lead to fatalities, loss of crops and livestocks, damage to infrastructures, as well as disruption of transport and communication. HPEs remain difficult to predict. Considerable efforts to improve the forecast skill for such severe events have been made in recent years, and significant progress has been realized through the development of kilometer-scale numerical weather NWP systems (Ducrocq et al. 2014) and data assimilation techniques (e.g., Kwon et al. 2018, Gustafsson et al. 2018). However, our ability to predict such high-impact events remains limited because of the lack of adequate high frequency, high-resolution vertically resolved water vapor (WV) observations in the low troposphere to be assimilated in NWP systems, and especially in the boundary layer (Weckwerth et al. 2004; Wulfmeyer et al. 2015; Leuenberger et al. 2020).

The implementation of an integrated prediction tool, coupling network measurements of WV profiles, and a NWP model, to precisely estimate the amount, timing, and locations of rainfall associated with HPEs up to $48 \mathrm{~h}$ in advance, is a strong societal demand, especially in regions of France most exposed to heavy rainfall (defined as maximum accumulation in excess of $150 \mathrm{~mm}$ per day, Ricard et al. 2012) as those located along the Mediterranean coast. Figure 1 shows the geographical distribution of HPEs obtained from rain gauges for the period 1970-2019) in southern France. Over this period, HPEs are most numerous in Languedoc-Roussillon, along the southern edge of the Cevennes range, between the Mediterranean coastline and the southern Alps, and along the eastern side of Corsica. The two most important HPEs seen in Fig. 1 are located in the Aude department and are related to the 12-13 November 1999 event (Nuissier et al. 2008; Ducrocq et al. 2008) and the 14-15 October 2018 event (Caumont et al. 2021). Large amounts of rainfall associated with these

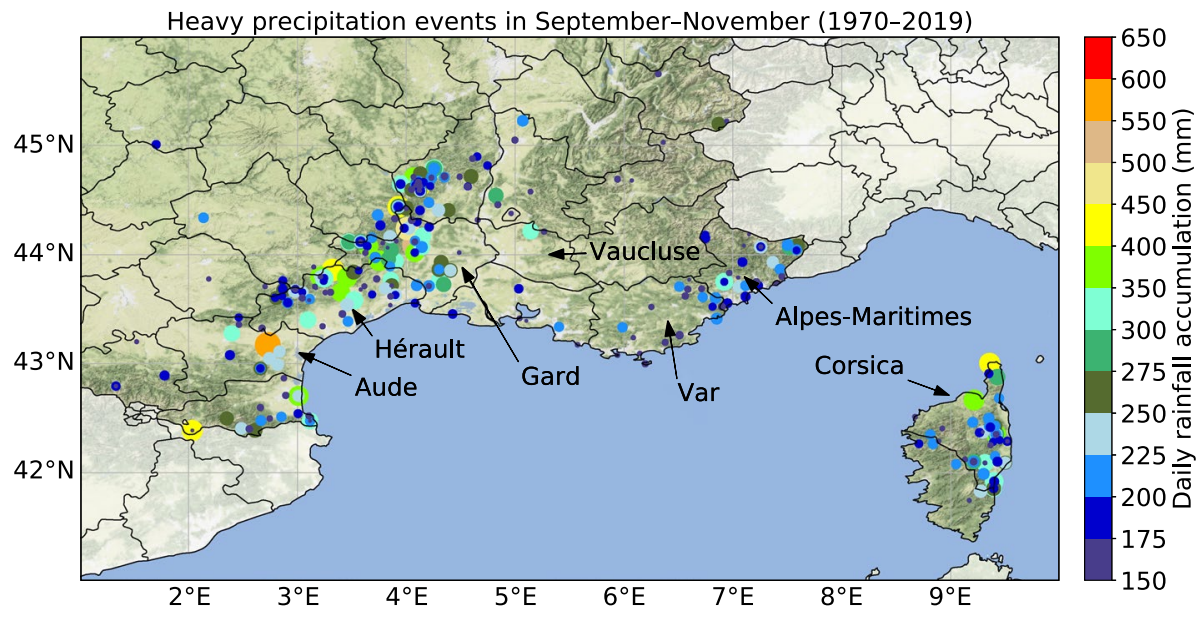

Fig. 1 Geographical distribution of heavy precipitation events defined as maximum accumulation $>150 \mathrm{~mm} /$ day and separated from other events by a distance of more $100 \mathrm{~km}$. The size of the circle is a function of accumulated precipitation for a given event. Map tiles by Stamen Design, under CC BY 3.0. Data by OpenStreetMap 
cases were attributed to strong synoptic forcing and associated with quasi-stationary mesoscale convective systems (MCSs) which, for instance, led to accumulated surface precipitation reaching about $620 \mathrm{~mm}$ for the former event (Ducrocq et al. 2008). Other remarkable events in the same area (Languedoc-Roussillon and Cevennes) have been observed in the Hérault and Gard which are also linked to catastrophic events such as the 13-14 October 1995 and 8-9 September 2002 cases, respectively (Ducrocq et al. 2008) also related to torrential rainfall cause by stationary MCSs. In the southern Alps area, remarkable HPE cases include the Vaison-La-Romaine event in the Vaucluse department (22 September 1992) and the Côte d'Azur event in the Alpes Maritimes department (3 October 2015). In addition, two other cases are included that have been identified during the hydrological Cycle in the Mediterranean Experiment First Special Observing Period (HyMeX SOP1) on 14 and 26 October and 2012 (Duffourg et al. 2016, 2018). Finally, a famous HPE in Corsica was the 31 October-1 November 1993 case which affected the eastern side of Island with up to $450 \mathrm{~mm}$ of rain in a day in several locations.

Southern France is a region stricken by an average of 7 HPEs per year during the fall (September to November) (Ricard et al. 2012, Ducrocq et al., 2014) as illustrated by Fig. 2 for the period 1970-2019. It is worth noting that HPEs can also occur outside of the September-November period, as for instance in December when more than an event per year can be observed. All other months exhibit less than one HPE per year, with the minimum in the monthly climatology being observed in June and July, which are the months less favorable for sustainability of HPEs (lower sea surface temperatures than in the fall and less eastward moving low pressure disturbances across the Mediterranean).

Furthermore, and in close connection with climate change issues, the analysis of extreme Mediterranean rainfall events for the French regions over the last few decades shows an intensification of heavy rainfall between 1961 and $2015(+22 \%$ on the annual maximum daily totals) and an increase in the frequency of the strongest Mediterranean episodes, particularly those exceeding the $200 \mathrm{~mm}$ threshold in $24 \mathrm{~h}$ (Ribes et al. 2019).

Accurate characterization of WV in the lower atmosphere is essential for quantitative precipitation forecasting associated with HPEs (e.g., Behrendt et al. 2011, and references therein). However, the spatial and temporal variability of the WV field is very high, notably due to the fact that water coexists in three phases in the atmosphere. Furthermore, WV is an essential atmospheric meteorological and climatological variable but one that

Fig. 2 Frequency of monthly heavy precipitation events per year averaged over the period 1970-2019, highlighting in red the three most likely months (September-October-November)

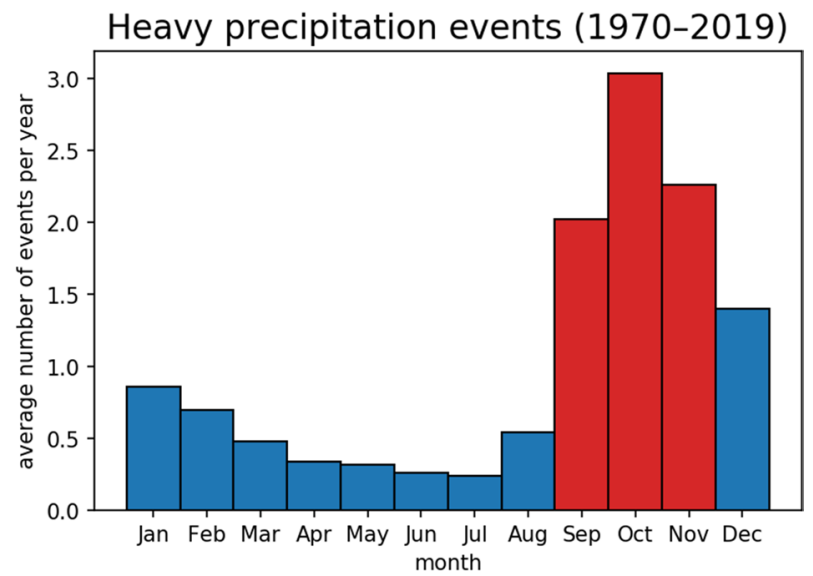

Springer 
is still difficult to measure, as WV concentrations can vary by three orders of magnitude in the troposphere (typically from $10 \mathrm{~g} \mathrm{~kg}^{-1}$ near the surface to $0.01 \mathrm{~g} \mathrm{~kg}^{-1}$ in the upper troposphere).

Despite the undeniable contribution of microwave and infrared sounders onboard satellites, the assimilation of atmospheric WV-related observations from space still suffers from many limitations: (i) insufficient vertical resolution and accuracy below $3 \mathrm{~km}$ to describe precisely the very strong gradients of the moisture profiles observed in the lower troposphere (Chazette et al. 2014; Wulfmeyer et al. 2015), i.e., in a region key to understand convective initiation and the life cycle of heavy precipitating systems, and (ii) poor temporal sampling due to the fact that infrared and microwave sounders are embarked on meteorological satellites and cannot fully grasp the strong temporal variability of the WV field. Global Navigation Satellite System Radio Occultation (GNSS RO) observation from the satellite provide information on humidity at high vertical resolution $(\sim 100 \mathrm{~m})$ down to 1 $\mathrm{km}$ above the Earth surface through the limb sounding. However, they suffer from 3 major drawbacks that currently limit their interest for data assimilation in the French limited area operational Application of Research to Operations at MEsoscale (AROME-France) model. First, the horizontal resolution of GNSS RO products is too coarse in the troposphere (a few hundred km, as they consist of path-integrated measurements) which is not appropriate for a fine scale NWP system (e.g., AROME-France has a 1.3-km grid size, and 90 vertical levels between the surface and $10 \mathrm{hPa}, 33$ of which are below $2000 \mathrm{~m}$ ). Second, GNSS RO observations do not allow to observe the WV in the first kilometer of the atmosphere which is of great importance for monitoring moisture upstream of HPE hotspots. Third, there are very few GNSS RO observations available in each AROME-France 1-h assimilation window. For instance, the WV products currently assimilated from the plethora of microwave, and infrared sensors on polar orbiting spacecraft only represent $15 \%$ of the data ingested in the AROME-France operational model. In conclusion, currently available GNSS RO products are not suitable for improving HPE forecast through data assimilation.

Currently, 85\% of the WV products assimilated in AROME-France come from surface stations, radar reflectivity near surface, aircraft, surface-based GNSS, and radiosoundings. However, only the latter can provide vertically resolved WV profiles above the surface, and this twice a day at best. Ground-based GNSS networks only provide integrated WV contents, whereas radars just provide indirect information on WV in precipitating systems. Surface stations only provide information on moisture very close to the surface, and aircrafts are currently very poorly equipped with moisture sensors.

Much of the AROME-France domain covers the Western Mediterranean which is usually upstream of convective systems, while observation systems used for assimilation (radar, GNSS, SYNOP stations) are primarily terrestrial. This is a major caveat because this is where the fast-evolving evaporation and air mass moistening processes take place that are crucial to understand and anticipate the development of HPEs downstream over southern France. This explains why HPEs in southern France are quite challenging to forecast with sufficient lead-time compatible with hazard warnings. Hence, the assimilation of data in the lower layers across the Western Mediterranean and available in near real-time will benefit prediction of HPEs at the mesoscale.

Unlike the instruments stated above, Raman water vapor lidars have the ability to measure water vapor profiles with high temporal and vertical resolution in the troposphere, making them ideal instruments for studying the evolution of water vapor in the troposphere in a fast evolving pre-HPE moist environment, provided that they are properly calibrated. Because they are rugged, easy-to-use instruments, Raman lidars are nowadays intensively used in the framework of measurement campaigns (e.g., Chazette 
et al. 2016a, b; Lange et al. 2019; Di Girolamo et al. 2020, among others). Furthermore, an increasing number of Raman lidars around the world have been automated and are operated in a continuous manner for the purpose of numerical weather prediction and climate monitoring (Goldsmith et al. 1998; Reichardt et al. 2012; Dinoev et al. 2013). The major drawbacks associated with the use of Raman lidars is that their emitted laser cannot penetrate clouds or fog more than few tens of meters.

The project WaLiNeAs (Water vapor Lidar Network Assimilation) aims at bringing together French, Italian, German, and Spanish scientists concerned with improving HPEs forecasts around the Mediterranean. The members of the international consortium have joined forces to tackle the issues and challenges highlighted above. This paper describes the rationale of the WaLiNeAs initiative as well as the measurement and assimilation strategies central to project. It also highlights the key expectations from the program funded by several agencies in France, Italy, Germany, and Spain.

\section{Challenges, objectives, and strategy}

In the framework of the WaLiNeAs initiative, we aim at implementing an integrated prediction tool to enhance the forecast of HPEs in southern France, based on the subhourly assimilation of vertically resolved water vapor observations in the lower troposphere. A consortium of French, German, Italian, and Spanish research groups will deploy a network of 6 autonomous WV lidars for providing measurements with high vertical resolution and accuracy across the Western Mediterranean in fall 2022, closing critical gaps in lower troposphere WV observations by current operational networks and satellites. The proposed WV lidar network has been designed to account for all relevant WV sources and transport patterns known to contribute to the generation of HPEs in southern France. This network will aim at demonstrating the benefit of the assimilation of vertically resolved WV data in the forthcoming version of the operational $1.3-\mathrm{km}$ grid size AROME-France NWP system (Brousseau et al. 2016; Montmerle et al. 2018) which enables ensemble-variational data assimilation for kilometer-scale prediction of heavy precipitation over southeastern France (Desroziers et al 2014). The ensemblevariational data assimilation system that will be available in 2022 will produce hourly analyses and will be operated with a rapid update cycle of assimilation of new observations at least each $15 \mathrm{~min}$.

The WaLiNeAs project is a unique, innovative initiative that will allow for assimilating lidar-derived WV profiles in the lower troposphere with hectometer-scale vertical resolution in near real-time conditions for a continuous period of at least 3 consecutive months. The benefit of WaLiNeAs to the academic and operational communities is dual: advance knowledge of the processes at play in the life cycle of HPEs and enhance the predictability of HPEs in southern France at scales relevant for meteorological studies. Both aspects are dealt with in the framework of WaLiNeAs.

Finally, the breakthrough science that will be carried out in the framework of WaLiNeAs concerns:

- Characterizing the predictability of HPEs and uncertainties in the prediction of the position, evolution, and the rainfall amount of the precipitating systems 
- Assessing the role of water vapor distribution over the Western Mediterranean on the characteristics of the moist inflow (origin, evolution, pathways) feeding deep convection leading to HPEs

- Investigating the role of Mediterranean cyclones in the water cycle and HPEs in the Western Mediterranean

- Understanding the impact of elevated tropical moist plumes on the life cycle of deep convection and related HPEs

- Advancing knowledge on the role of dry intrusions on HPE in cases of frontal precipitation

The Raman lidar-derived WV data acquired in the framework of the WaLiNeAs project will be made available to Météo-France shortly after being acquired and will be assimilated up to 96 times per day. The focus of the project will be on providing high quality lidarderived WV data in the first $3 \mathrm{~km}$ of the atmosphere, where no other observational technique can provide adequate data. To that respect, the two most cutting edge aspects of the project are as follows: (i) the near real-time processing and qualification of the lidar data (with WV profiles in the lower troposphere available every $15 \mathrm{~min}$ ) and (ii) the proposed system (four-dimensional ensemble variational — 4DEnVar (Desroziers et al. 2014) — with kilometric resolution) for the assimilation of qualified lidar data acquired in the lower troposphere, day and night.

Besides demonstrating the potential of WV lidar data assimilation in the AROMEFrance system, an ancillary objective of the project is also to show that Raman lidars can be left to operate continuously almost unattended for a period of at least 3 months. It is a prerequisite in the perspective of future/further deployment of operational Raman lidar systems meant to fill the observational gaps in water vapor in the lower troposphere of the current operational observation networks and satellites. This project can be considered a test bed for the concept of operational use of Raman lidars to be assimilated in a kilometerscale NWP system. In all cases, in order for Raman lidars to be used more broadly in an operational context by meteorological services, reducing initial cost for installation, as well as maintenance frequency and cost, will be necessary.

The WaLiNeAs project builds on previous experience of the consortium partners, namely:

- Wulfmeyer et al. (2006) have assimilated airborne WV lidar observations acquired during a case study of the International $\mathrm{H}_{2} \mathrm{O}$ project (IHOP) with the MM5 mesoscale NWP system and its four-dimensional variational (4D-Var) assimilation system.

- Grzeschik et al. (2008) extended the previous work to the assimilation of the WV observations provided by a ground-based network of Raman lidar systems.

- Bielli et al. (2012) used a pre-operational version of the Météo-France AROME-France NWP system (Seity et al. 2011) and its associated 3D-Var high-resolution assimilation system to evaluate the impact on the quantitative precipitation forecasts of the Convective and Orographically-driven Precipitation Study (COPS) airborne lidar observations collected during July 2007. A continuous assimilation cycle updated every $3 \mathrm{~h}$ was run over a month to provide the initial conditions of a sequence of $30 \mathrm{~h}$ forecasts carried out over 19 consecutive days.

- An ambitious effort has been conducted to assimilate water vapor mixing ratio observations from the airborne lidar LEANDRE 2 (Lidar Embarqué pour l'étude des Aérosols, des Nuages, de la Dynamique, du Rayonnement et des Espèces minoritaires, developed at LATMOS, Guyancourt, France) and the two ground-based Raman lidars located in 
Menorca (the Weather Atmospheric LIdar (WALI) developed by LSCE, Gif-sur-Yvette, France) and Candillargues (the BASILicata Lidar (BASIL) developed by the University de la Basilicata, Potenza, Italy) as part of the reanalysis project aiming at assimilating the research observations collected during the HyMeX SOP1 (Richard et al., 2014; Fourrié et al. 2015, 2019, 2021). One month of ground-based Raman Lidar data and airborne lidar observations from approximately 20 flights were used in the reanalyses conducted by Fourrié et al. (2015, 2019, 2021).

- Thundathil et al. (2020) assimilated even both water vapor and temperature lidar data into the weather and research Forecast model on the convection-permitting scale applying a 3D-Var rapid update cycle and found that especially the assimilation of moisture results in a significant improvement of the model fields.

All these studies have shown encouraging results in terms of the impact of lidar-derived WV data assimilation on quantitative precipitation forecasts. However, they are based on a limited number of cases, date from a limited number of lidar systems ( 2 at most) and too short assimilation periods to allow for general conclusions to be drawn in a statistical sense regarding the impact of WV lidar observation assimilation on the quantitative precipitation forecast.

\section{Implementation of WaLiNeAs}

As part of the WaLiNeAs initiative, the WV Raman lidars will be operated continuously during 3 months starting early September 2022, to cover the period most propitious to HPEs in southern France (see Figs. 1 and 2). The duration of the operation is imposed by the necessity to have a long enough record in order for the WV profiles assimilated to have a significant impact on the moisture fields in the model forecasts. This long data set is crucial to assess statistical errors and to genuinely evaluate the benefit of Raman lidar water vapor data assimilation for operational NWPS.

This proposal accounts for the fact that Raman lidar technology has reached the level of maturity needed for unattended, continuous operation. Since more than 10 years, automated Raman lidar systems are operated in automatic mode at several observatories and research institutions (Goldsmith et al. 1998; Balin et al. 2004; Reichardt et al. 2012; Dinoev et al. 2013; Brocard et al. 2013; Leuenberger et al. 2020). Recently, also mobile systems became available which can be moved for field experiments: This is attested by the large data sets acquired by WALI and BASIL in the field during HyMeX SOP1 (Chazette et al. 2016a, b; Di Girolamo et al. 2020) or by the automated Raman lidar ARTHUS (Atmospheric Raman Temperature and Humidity Sounder, Lange et al. 2019) of the University of Hohenheim that operated from a ship for over a month during the EUREC ${ }^{4} \mathrm{~A}$ campaign (Stevens et al., 2021). Figure 3 shows examples of time-height cross-sections of WV mixing ratio measured with WALI from 17 September to 28 October 2012 over Menorca, Spain (Fig. 3a), with BASIL over the 12-day time period from 0000 UTC on 17 October 2012 to 0000 UTC on 27 October 2012 over Candillargues, France (Fig. 3b), and with ARTHUS between 11 and 19 February 2020 on-board the research vessel Maria S. Merian over the Tropical Atlantic Ocean during the EUREC ${ }^{4} \mathrm{~A}$ campaign (Fig. 3c). During HyMeX, WALI acquired $1000 \mathrm{~h}$ of WV mixing ratio profiles while being operated continuously during SOP1 and BASIL acquired over $600 \mathrm{~h}$ of data during the same period, but was operated continuously for 3 days at a time, with a sampling strategy focused on 
Fig. 3 a Time-height cross-section of water vapor mixing ratio acquired during the HyMeX SOP1 with the WALI system of LSCE ( $1000 \mathrm{~h}$ of data) from 17 September to 28 October 2012 over Menorca. The temporal resolution is $1 \mathrm{~h}$, and a gliding average of $15 \mathrm{~m}$ was applied in the vertical. b Same as (a) but measured by BASIL over the 12-day time period from 0000 UTC on 17 October 2012 to 0000 UTC on 27 October 2012 during HyMeX. The temporal resolution is $5 \mathrm{~min}$, and a gliding average of $150 \mathrm{~m}$ was applied in the vertical. c Same as (a) measured by ARTHUS collected between 11 and 19 February 2020 onboard the research vessel Maria S. Merian within the EUREC4A deployment. The temporal resolution is $10 \mathrm{~s}$, and a gliding average of $50 \mathrm{~m}$ was applied in the vertical. The black/white areas correspond to missing data due to the limitation of the detection system during the daytime. The black areas correspond to missing data due to the limitation of the detection system during the daytime or lidar system operation stoppage

intensive observation periods only. During EUREC ${ }^{4}$ A, ARTHUS collected useful data between 24 January and 19 February 2020, for approximately $620 \mathrm{~h}$.

We aim at operating a dedicated network of 6 autonomous Raman WV lidars over the Western Mediterranean in locations shown in Fig. 4 to monitor the low-level and elevated moisture towards regions most likely to be hampered by HPEs in southern France in the fall as illustrated by Fig. 5, and also discussed by Ricard et al. (2012, see their Fig. 1), namely, Languedoc-Roussillon (LR), Cévennes-Vivarais (CV), southern Alps (SA), and Corsica (CO). Five of the six Raman lidar systems will be deployed specifically for WaLiNeAs. The 6th system is operating as a fixed, long-term monitoring station. We did not conduct a data targeting study (as in Majumdar 2016) to select the location of the 5 mobile lidar stations because of the lack of tools to perform such studies at the convective scale with the AROME model. The low-level moisture pathways are inspired by the composite analysis for 40 HPEs made by Ricard et al. (2012), for each of the target areas based on 700-1000-hPa integrated moisture flux and 925-hPa wind speed (see their Fig. 11). We are considering sites such as Barcelona and the islands of Menorca in Spain (to monitor the southerly flow upwind of LR, CV and SA, as well as elevated plumes from tropical Africa), Ajaccio in Corsica (to monitor the southerly flow upwind of $\mathrm{CO}$ and the easterly flow upwind of LR), Narbonne in the Aude Valley (to monitor the westerly flow from the Atlantic Ocean as well as event over LR), Cannes (to monitor the easterly flow upwind LR and SA), and Montpellier (to monitor the southerly flow and boundary layer upstream of $\mathrm{CV})$. The main moisture patterns leading to HPE in southern France shown in Fig. 5 are also based on prior knowledge (Duffourg and Ducrocq 2013) and on the most recent work conducted on HyMeX SOP1, e.g., Chazette et al. (2016a), Di Girolamo et al. (2016), Duffourg et al. (2018), and Khodayar et al. (2018), among others. In an Observing System Simulation Experiment context, Yoshida et al. (2020) have shown that assimilating Raman lidar water vapor data on the windward side of heavy precipitation was likely to improve precipitation forecasts.

The worth of installing a Raman lidar system to monitor WV upstream of HPE-prone target area is further illustrated in Fig. 6. In Fig. 6a, we show the density distribution of all WV vertical profiles acquired with the WALI system installed in the city of La Ciutadella, in Menorca, during the entire HyMeX SOP1 (see Fig. 4 for the location of La Ciutadella). WALI was operating upstream of target areas in southern France, namely, LR, CV, and SA. The distribution highlights the spread in WV mixing ratio observed upstream of the Western Mediterranean coastline (color) around the mean profiles (black solid line). Figure 6a stresses out that in the course of the HyMeX SOP1, the highest occurrence of WV was found below $2 \mathrm{~km}$ amsl (where WV mixing ratio in on average comprised between 5 and $15 \mathrm{~g} \mathrm{~kg}^{-1}$ ) and above $5 \mathrm{~km}$ amsl (where values are very low, less than $1.5 \mathrm{~g} \mathrm{~kg}^{-1}$ ). The spread below $2 \mathrm{~km}$ amsl reaches $6 \mathrm{~g} \mathrm{~kg}^{-1}$ for $\mathrm{WV}$ mixing ratio values occurring more than $30 \%$, and more than doubles for WV mixing ratio values occurring more than $10 \%$ of the time. Figure $6 \mathrm{~b}$ and 

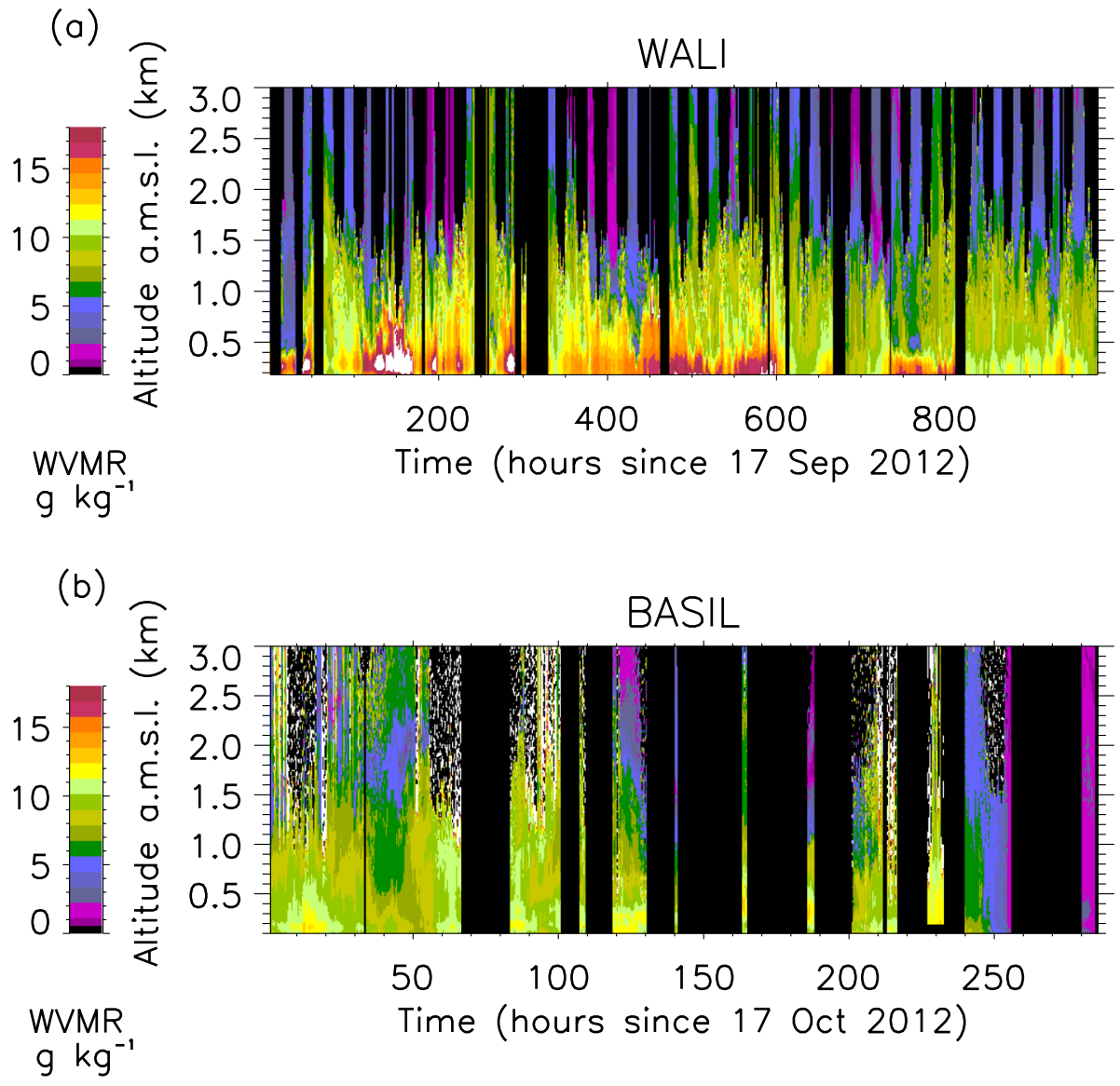

(c)

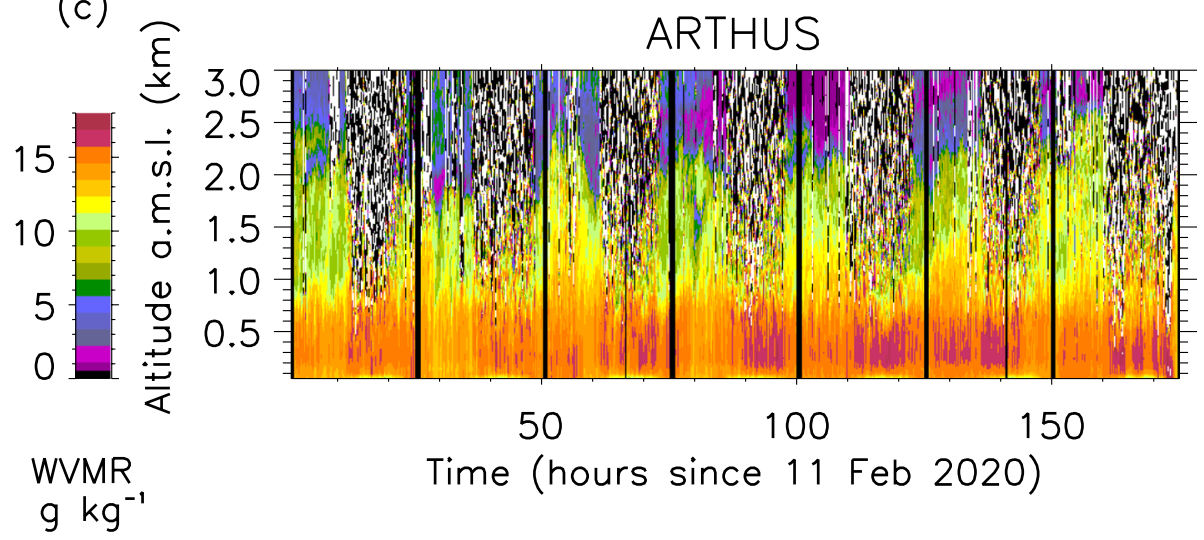

c show the density distribution of WV mixing ratio in HPE-free conditions and in HPE conditions, respectively, for two 5-day periods. The HPE-free period selected is from 2 to 6 October 2012, during which no HPEs were observed in the Western Mediterranean basin. 

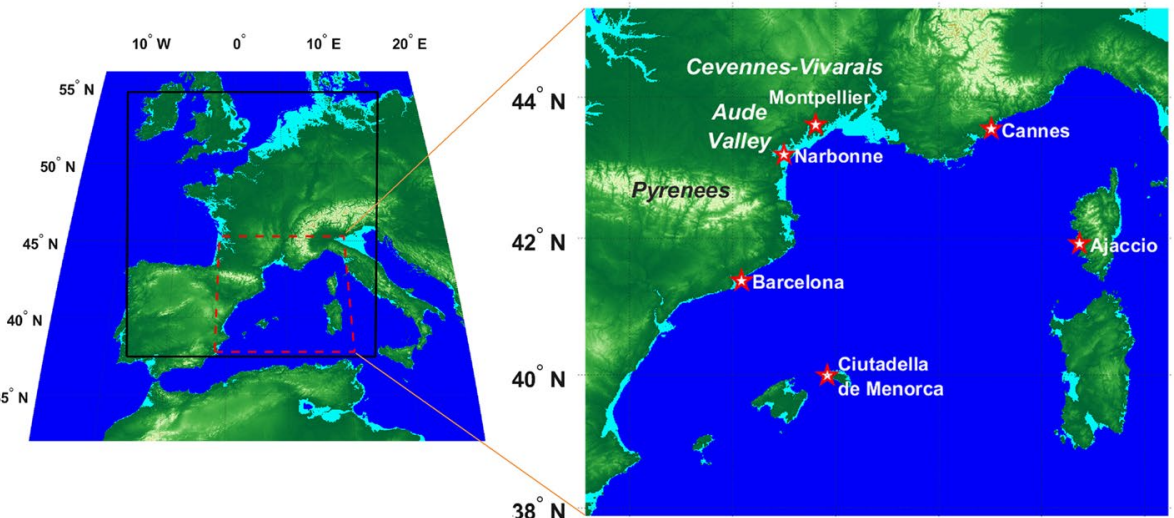

Fig. 4 Left: orography of the AROME-France domain (area delimited by the black contour). Right: zoom on the region of operation of the Raman Lidar Network with the location (city) of each lidar highlighted with red and white stars

For the HPE conditions, we selected the period from 7 to 11 October 2012, up to 4 days ahead of HPE events observed in the CV, namely, IOP12a on 11-12 October (Khodayar

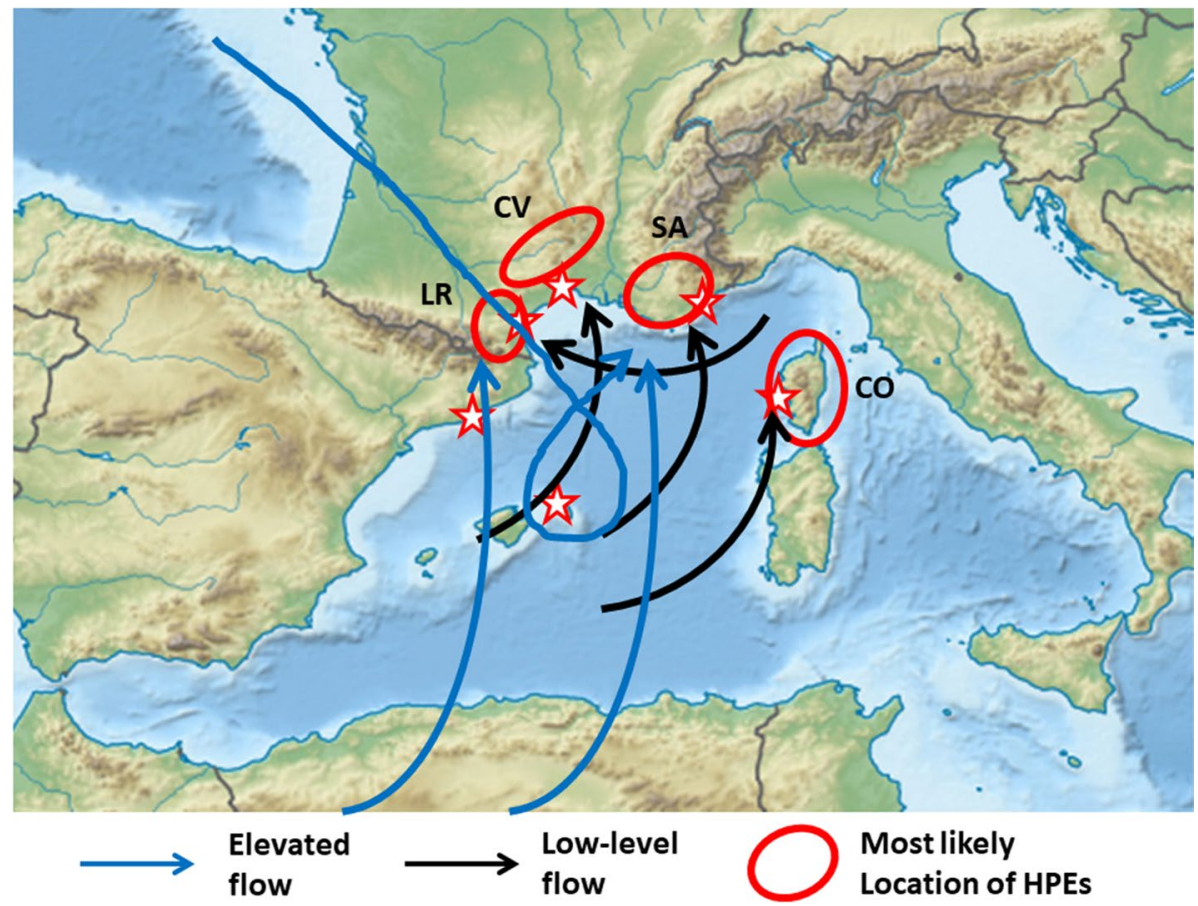

Fig. 5 Regions most likely to be impacted by HPEs (red circles) together with main flow patterns in the low levels (black arrows) and in altitude (2-4 km, blue arrows). LR is Languedoc-Roussillon, CV is, CévennesVivarais, SA is southern Alps, and CO is Corsica. The red and white stars indicate the location of Raman Lidar systems in the WaLiNeAs Network 

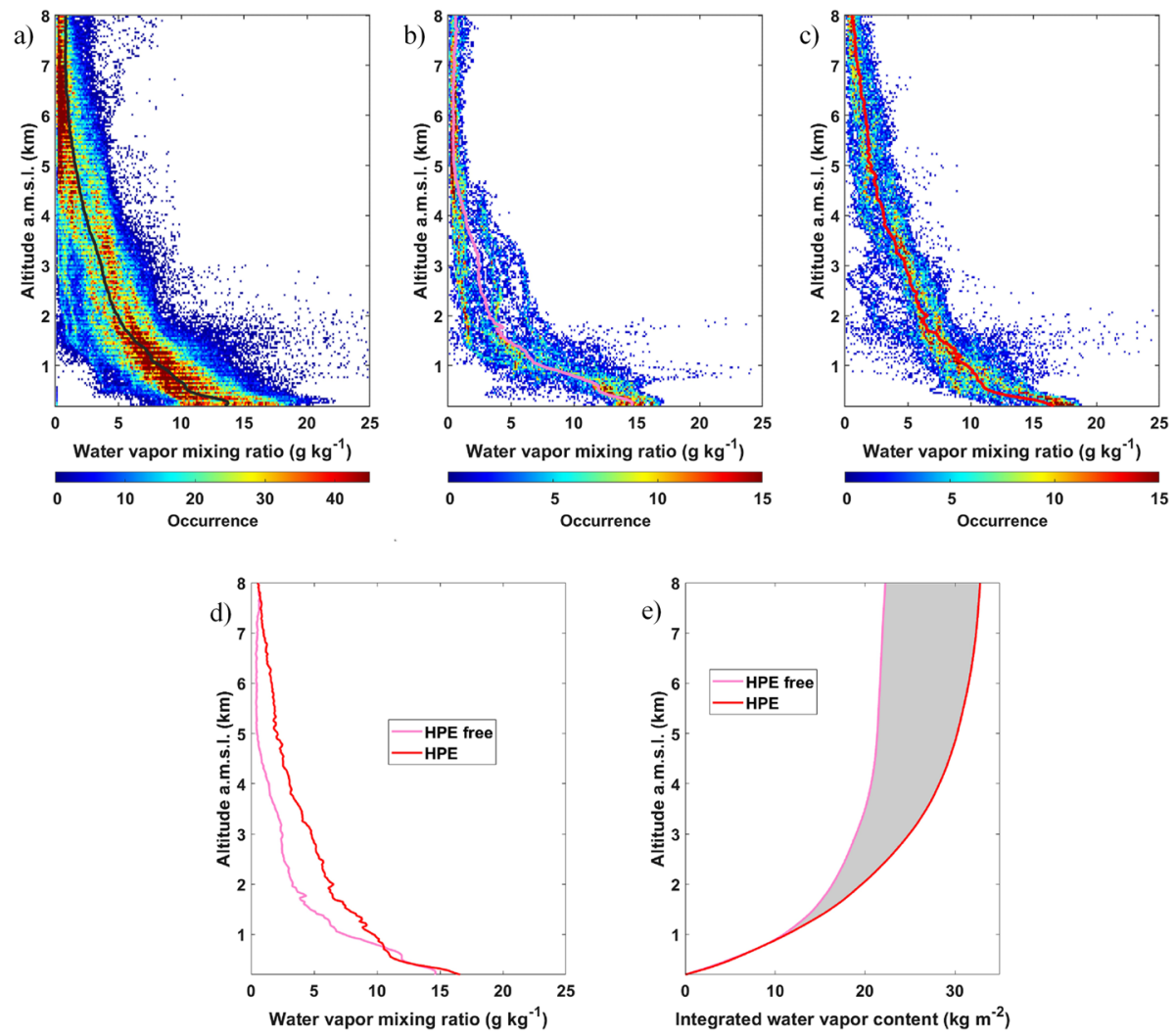

Fig. 6 a Density distribution of all WV vertical profiles acquired with WALI during the HyMeX SOP1 (see Fig. 5a). The black solid line indicates the barycenter of the distribution at each altitude bin. The occurrence of water vapor mixing ratio values is color code. b Same as (a), but for the profiles acquired in HPE-free conditions from 2 to 6 October 2012. The pink solid line indicates the barycenter of the distribution at each altitude bin. c Same as (b), profiles acquired in HPE conditions from 7 to 11 October 2012. The red solid line indicates the barycenter of the distribution at each altitude bin. $\mathbf{d}$ Average vertical distribution of WV mixing ratio as a function of altitude in the HPE-free case (pink solid line) and the HPE case (red solid line). e Integrated water vapor content as a function of altitude for the HPE-free case (pink solid line) and the HPE case (red solid line). The integrated content is computed at the integral of the lidar-derived specific humidity profiles from the ground upward. The shaded area highlights the difference between the HPE-free and HPE distribution

et al., 2018) and IOP 13 on 14-16 October (Duffourg et al. 2018). Above $2 \mathrm{~km}$ amsl, the WV mixing ratio distribution for the no HPE period (Fig. 6b) is skewed towards small values than in the HPE period (Fig. 6c) up to $8 \mathrm{~km}$ amsl. The average WV mixing ratio profiles, computed as the barycenters of the distributions at each altitude bin (pink and red solid lines, for the HPE-free and HPE periods, respectively), overlain in Fig. 6b and c, are also shown in Fig. 6d. They highlight that, between 0.75 and $8 \mathrm{~km}$ amsl, the troposphere is significantly moister in HPE conditions than in HPE-free conditions. The marine boundary layer is also slightly more moist in HPE conditions below $300 \mathrm{~m}$ amsl. The integrated water vapor content profile, computed at the integral of the lidar-derived specific humidity profiles from the ground upward, in HPE-free conditions (pink solid line) and in HPE conditions (red solid line), is shown in Fig. 6e. Over the depth of the lower troposphere, i.e., below $8 \mathrm{~km}$ amsl, the difference between HPE and HPE-free conditions reaches $10 \mathrm{~kg} \mathrm{~m}^{-2}$. The integrated water 
vapor content in HPE conditions $\left(\sim 33 \mathrm{~kg} \mathrm{~m}^{-2}\right)$ is comparable to those derived from global positioning system by Khodayar et al. (2018) during IOP 12, even though slightly smaller due to the fact that we are only considering partial columns. The above analysis clearly suggests that Raman lidar-derived WV mixing ratio profiles collected in Menorca in a period up to 4 days ahead of HPEs in the CV area are significantly moister than for a 4-day period when no HPE events are observed in southern France, thereby providing data worthy of assimilation in a HPE forecasting context.

The 5 mobile Raman lidar systems that will be operating in the field are rugged and transportable systems that have operated in many locations in recent years:

- The Weather Atmospheric LIdar (WALI, Chazette et al. 2014) developed at LSCE, which was involved in the SOP1 of HyMeX (Chazette et al. 2016a,b; Di Girolamo et al. 2020) or during the Pollution in the ARCtic System (PARCS) project (Totems et al. 2019) and recently during the Lacustrine-Water vApor Isotope inVentory Experiment (L-WAIVE) project (Chazette et al. 2021)

- The Airborne Lidar for Atmospheric Studies (ALiAS, Chazette et al. 2012, 2017, 2019, 2020) developed at LSCE

- The Lidar for Automatic Atmospheric Surveys using Raman Scattering (LAASURS; Baron et al. 2020) developed at LSCE

- The University of BASILicata ground-based Raman Lidar system (BASIL), which was involved in HyMeX (Di Girolamo et al., 2009, 2016, 2017, 2020; Stelitano et al. 2019)

- The Atmospheric Raman Temperature and Humidity Sounder (ARTHUS, Lange et al. 2019) of the University of Hohenheim

The fixed Raman lidar system that will operate in Barcelona is the lidar system of Universitat Politècnica de Catalunya (UPC, Muñoz-Porcar et al. 2018, 2021) which is in operation since 1993 and is part of the European Aerosol Research Lidar Network (EARLINET) since 2000 and of the European Research Infrastructure for the observation of Aerosol, Clouds, and Trace Gases (ACTRIS) since 2011.

For details on the instruments (emission unit, reception unit, spatio-temporal sampling strategy, etc.), the reader is referred to the existing body of literature that are listed above and are summarized in Table 1. LAASURS and ALIAS will be upgraded to WV Raman lidar prior to the start of the fall 2022 field campaign.

The lidar data will be collected, disseminated, and monitored in real time, as would be done in an operational context. Since it is unrealistic to set up a full real-time operational NWP system dedicated to a single observing system (the cost of real-time high-performance computing with human supervision far exceeds funds allotted to WaLiNeAs), the lidar data assimilation will be evaluated in a quasi-operational environment, i.e., with the same tools and data, but without the associated resources necessary for real-time operations. This framework will allow deriving results that will hold true for an operational context, at an economic cost.

\section{Project organization and structure}

The project is organized around 4 scientific tasks aimed at developing an innovative integrated forecasting tool in order to pave the way towards an operational, breakthrough HPErelated hazard warning capability for southern France and Corsica as well as work on the cutting-edge science linked with the development of such an innovative tool. 


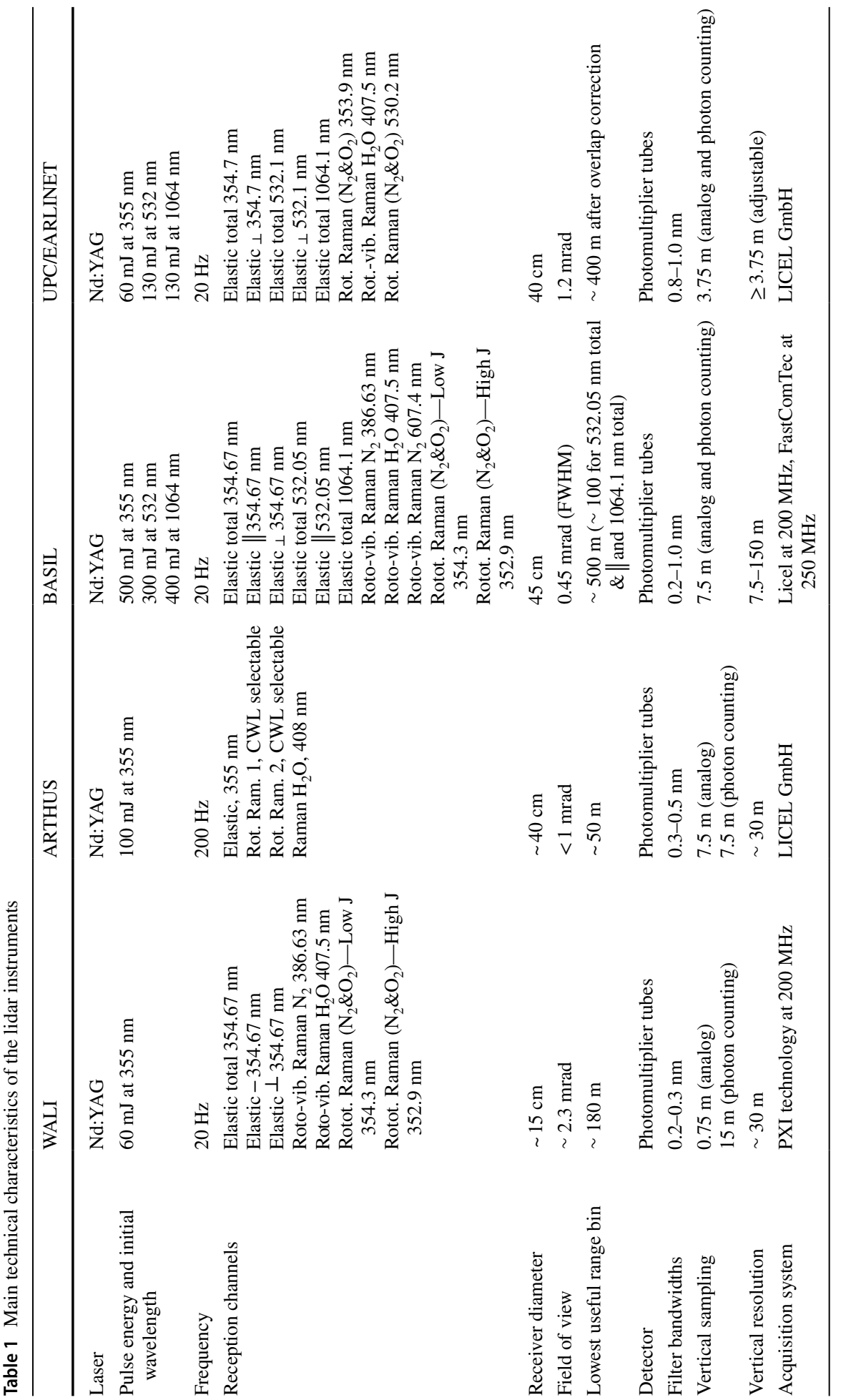




\subsection{WP1 Field campaign}

WP1 (field campaign) will drive the necessary experimental/instrumental deployments to achieve the acquisition of WV profiles and the near real-time transmission of the data to the French Weather Service. This will include the upgrade of the Raman lidar systems to be deployed, as well as the definition of the exact location of the implementation sites and complementary instruments, the data transmission protocols and data quality assurance, as well as the characterization of system calibration. WP1 is organized around 3 main activities.

\subsubsection{Upgrade and preparation of lidar systems}

The WV-Raman upgrades consist in adding a $\mathrm{H}_{2} \mathrm{O}$-Raman channel on each lidar and the development of an acquisition chain. The lasers will be upgraded in energy to improve the signal to noise ratio. This will ensure that the output energy of the systems as well as their performances (precision, systematic error on WV profiles, etc.) will be same as the operational WALI system. Note that these two mini-lidar systems will be autonomous and connected via Internet. Prior to the field campaign, a thorough intercomparison of WV profiles between the operational WALI Raman lidar and the upgraded Raman systems (LAASURS and ALIAS) will be undertaken.

\subsubsection{Real-time data processing and data transmission}

For real-time purpose, the six Raman lidars will deliver 2-4 profiles per hour which are averaged over $15 \mathrm{~min}$ with vertical resolution of $100 \mathrm{~m}$ and a targeted root-mean-squareerror of $0.4 \mathrm{~g} \mathrm{~kg}^{-1}$ in the first $3 \mathrm{~km}$, day and night. Performances are expected to exceed these target values during the night for all systems (WALI, ALIAS, LAASURS, BASIL, ARTHUS, and UPC/EARLINET). In addition to the water vapor mixing ratio profiles, the statistical uncertainties of these profiles as well as the atmospheric variance determined with the auto-covariance technique (Lenschow et al. 2000) will be provided. It is a significant advantage of the lidar technique that also these error profiles can be determined and consequently be used for the data assimilation.

The WV profile acquisition, processing, and transmission sequence is anticipated to span over 25 min (Fig. 7). For the analysis at XXXX UTC, the assimilation system will

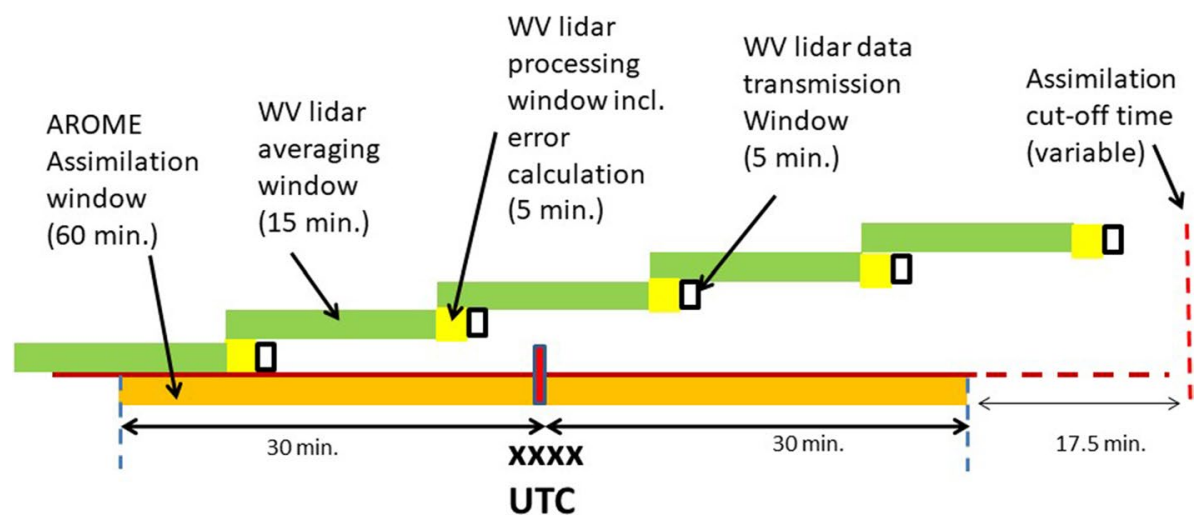

Fig. 7 Timeline of the WV lidar data transmission sequence from the operating sites to Météo-France for assimilation of near real-time WV profiles in the AROME-France NWP system 
ingest observations made between XXXX UTC $-30 \mathrm{~min}$ and XXXX UTC $+30 \mathrm{~min}$. Every $15 \mathrm{~min}$ between XXXX UTC $-30 \mathrm{~min}$ and XXXX UTC $+30 \mathrm{~min}$, the WV lidar data (resulting from a 15-min average) will be processed, and errors calculated within a 5-min window and then transmitted in an additional 5-min window (Fig. 7). There will be some overlap in the processing of each profile: As soon as the 15-min measurement period (in green in Fig. 7) is over, there is both the start of the next 15-min measurement period and the start of the processing ( $5 \mathrm{~min}$, in yellow) + transmission $(5 \mathrm{~min}$, in white framed in black) of the one that has just ended. The measuring periods for an assimilation window would be [ XXXX-30 min; XXXX + $30 \mathrm{~min}$ ], [XXXX-37.5 min; XXXX-22.5 min], [ XXXX-22.5 min; XXXX-7.5 min], [ XXXX-7.5 min; XXXX+7.5 min], [ $\mathrm{XXXX}+7.5 \mathrm{~min} ; \mathrm{XXXX}+22.5 \mathrm{~min}]$, [ XXXX +22.5 min; XXXX+37.5 min]. So, for a cut-off time greater than or equal to $\mathrm{XXXX}+47.5 \mathrm{~min}$, there are 4 profiles for the corresponding analysis. The end of the last 5-min transmission window should occur before the so-called cut-off time. The cut-off time is the time after the hour of analysis until which one waits for the observations to arrive before starting the calculations. In the current AROMEFrance assimilation system, this cut-off is not constant and varies according to the time of day (it varies from $\mathrm{T}+20 \mathrm{~min}$. to $\mathrm{T}+3 \mathrm{~h} 15$ ). Depending on the cut-off time, up to $6 \mathrm{WV}$ lidar profiles will be assimilated in each hourly 4DEnVar analysis. This sequence is subject to adaptation depending on the evolution of the high computational performances at Météo-France and performances of the WV lidars in the field.

\subsubsection{WV lidar intercomparison}

After the conduct of the field campaign, the consortium will also deliver a consistent, selfcoherent, and validated WV data set of lidar profiles, including uncertainties at high spatiotemporal resolution for data assimilation experiments. This effort will include intercomparison of WV lidar-derived profiles between the 3 operational systems WALI, BASIL, and ARTHUS. Comparison between WALI, LAASURS, and ALIAS will be conducted at LSCE before and after the field campaign. The long-term stability and calibration of the WV lidar systems will also be monitored throughout the field campaign using a mobile radiosounding unit that will be operated alongside each of the 6 Raman lidar systems at the beginning, mid-way through, and at the end of the campaign.

\subsection{WP2 Data monitoring}

WP2 (data monitoring) aims at Raman lidar data assimilation in AROME-France. This includes evaluating and optimizing how the observations can be used in the data assimilation system. For this, the ability of the model to simulate the physical quantity that is observed must be ensured. In practice, this is done through the "monitoring" of observations, i.e., the computation of observation-minus-background statistics, where "background" refers to short-term forecasts that will be blended with observations during the data assimilation process. Such a monitoring requires some preliminary work. To compare observations and the background, a common physical space has to be chosen, which needs to be close to that of the raw measurements to avoid the introduction of retrieval errors, while lending itself to the simulation from the model prognostic variables. The choice of this physical space in terms of geometry, physical quantity, and observation processing (time-space averaging, filtering) will be carefully assessed based on the horizontal and vertical resolutions of the current AROME-France version (e.g., $1.3 \mathrm{~km}$ ) and the 
15-min period of observations use. The current version of AROME-France uses a threedimensional variational (3D-Var) algorithm to assimilate weather data. A four-dimensional ensemble-variational (4DEnVar) data assimilation system will be available in 2022 to replace the current 3D-Var data assimilation system. It will be used in place of the 3D-Var data assimilation system for the WaLiNeAs project.

A near real-time monitoring will be set up during the field campaign scheduled in the fall of 2022 that will enable the evaluation of the statistical consistency between the observations and the model background. Such a real-time monitoring is usually performed at operational weather forecasting centers to detect gross errors such as hardware failure, calibration drift, or transmission losses. The monitoring performed in the framework of WaLiNeAs will ensure that the data are collected as expected and, if needed, allow for corrective action to be taken immediately so as to minimize any data loss.

After the field campaign, observation-minus-background statistics will be performed on the consistent, self-coherent, and validated data set of lidar profiles, once it is available (WP1). The objective is to compare to which extent the real-time and post-processed lidar data differ with respect to the model. Depending on the results, observation-minusbackground biases will be removed so as to comply with the data assimilation technique assumptions. The resulting lidar data sets and observation operator will be used in WP3 for the data assimilation experiments.

\subsection{WP3 Lidar data assimilation}

WP3 (lidar data assimilation) is focused on the post-campaign work on the assessment of the lidar data impact in the assimilation scheme. Since the objective of the project is to prove the feasibility and benefit of assimilating lidar data in an operational context, the assessment of the impact of the lidar data assimilation will be carried out by performing data assimilation experiments with the AROME-France system. The proven methodology of observing system experiments will be used. It consists in running two different experiments: the reference experiment, while the data assimilation experiment will additionally assimilate lidar data. So, the reference experiment will already assimilate all routinely available observations, and thus the impact of lidar observations will translate the ability of this new observing system to complement existing observing systems. With this methodology, the impact of the lidar data assimilation is simply obtained by contrasting the weather forecasts obtained by each of the two experiments with respect to an independent observational data set (e.g., precipitation amounts measured by rain gauges).

Data assimilation experiments will be performed for the two data sets prepared in WP1 and WP2: a set of lidar data collected in real time and a set of consistent, self-coherent, and validated lidar data. The real-time data set will provide baseline results that will show which benefit can readily be obtained with the current real-time data processing. The postprocessed data set will show to which extent additional processing may improve the quality of the weather forecasts. This will likely lead to recommendations on the lidar data processing for future operational exploitation in NWP systems.

\subsection{WP4 HPE-related science}

WP4 (HPE-related science) is expected to provide an improved representation of the highly variable spatial-temporal distribution of WV in the AROME-France analyses from the advanced data assimilation implemented in this project that will in turn lead to an overall 
improvement of the complex thermodynamical and dynamical processes controlling the life cycle of HPEs. We will investigate the impact of the WV profiles processing (realtime vs validated lidar data) on (i) the WV distribution over the Western Mediterranean in the AROME-France model and (ii) the prediction of the position, evolution, and the rainfall amount of the precipitating systems and HPEs encountered during the 3-month field campaign. The results will also be compared to AROME-France reference simulations in which lidar-derived WV profiles are not assimilated to further emphasize the worth (or lack thereof) of assimilating such data in the French NWP system. In addition, with a similar approach, we will examine what is gained in terms of advancing our knowledge of complex processes pertaining to the characteristics of the moist inflow (origin, evolution, pathways) feeding deep convection leading to HPEs. We will also study the impact of dry intrusions from the upper troposphere and moist tropical plumes on HPEs encountered during the campaign.

\section{Outlook}

This project aims at the development of all-weather, unattended, rugged, and operational Raman lidar systems for smart monitoring of the environment, and WV in particular. The WaLiNeAs project aims at developing the test bed of an integrated prediction tool, coupling network measurements of WV profiles, and a weather forecast model to precisely estimate precipitable water upstream of an event up to $48 \mathrm{~h}$ in advance in southern France. This project is highly innovative and will lay the foundation for a future integrated warning tool aiming to prevent natural hazards associated with HPEs as often experienced along the Mediterranean coastline. Once the proof of concept is validated in the framework of the WaLiNeAs project, similar integrated tools may be applied in other parts of the world to avoid similar natural hazards.

The highest risk for the project lies with the meteorology and the possible lack of heavy precipitation events during the fall of 2022. However, the length of the field campaign (3 months) is the best insurance that extreme events will happen somewhere in northwestern Mediterranean. Nevertheless, on average, 7 HPEs (daily rainfall $>150 \mathrm{~mm}$ ) occur every year between September and November (Ricard et al. 2012, Fig. 2). Furthermore, even in the case of lower than average HPE activity in southern France, the network data will be beneficial to the AROME-France forecasts, and a positive impact is expected on average skill scores and in the case of southern maritime inflow situation. Furthermore, experience learned from the lidar data processing in near real time and assimilation in NWP systems will still be extremely valuable to make recommendation on the use of WV lidars for future operational NWP systems. In all cases, the uttermost important objective of the project is to contribute to increase the accuracy of forecasts of quantitative precipitation in order to satisfy the societal demands in terms of amount, timing, and basin-specific locations of rainfall and flash flooding.

Acknowledgements The authors would like to thank Evelyne Richard and Mathieu Nuret, now retired, who have contributed to the original version of the WaLiNeAs proposals submitted to ANR in 2018 and 2019. The authors wish to thank the reviewers for their time and their thoughtful comments that helped improve the manuscript.

Funding This work is a follow on initiative to the HyMeX programme supported by MISTRALS and the Agence Nationale de la Recherche WaLiNeAs Grant ANR-20-CE04-0001. Additional funding was also obtained from the H2020 program of the European Union (grant agreement nos. 654109, 778349, 871115), the Spanish Ministry of Science and Innovation (ref. PID2019-103886RB-I00), the Spanish Ministry of Economy, Industry and Competitiveness (ref. CGL2017-90884-REDT), and the Unit of Excellence Maria de Maeztu (ref. MDM-2016-0600) financed by the Spanish Agencia Estatal de Investigación. 


\section{Declarations}

Conflict of interest The authors declare no competing interests.

\section{References}

Balin I, Serikov I, Bobrovnikov S, Simeonov V, Calpini B, Arshinoc Y, van den Bergh H (2004) Simultaneous measurement of atmospheric temperature, humidity, and aerosol extinction and backscatter coefficients by a combined vibrational-pure-rotational Raman lidar. Appl Phys B 79:775-782

Baron A, Chazette P, Totems J (2020) Remote sensing of two exceptional winter aerosol pollution events and representativeness of ground-based measurements. Atmos Chem Phys 20:6749-6768. https:// doi.org/10.5194/acp-20-6749-2020

Behrendt A, Pal S, Aoshima F, Bender M, Blyth A, Corsmeier U, Cuesta J, Dick G, Dorninger M, Flamant C, Di Girolamo P, Gorgas T, Huang Y, Kalthoff N, Khodayar S, Mannstein H, Träumner K, Wieser A, Wulfmeyer V (2011) Observation of convection initiation processes with a suite of stateof-the-art research instruments during COPS IOP8b. Q J Roy Meteorol Soc 137(S1):81-100

Bielli S, Grzeschik M, Richard E, Flamant C, Champollion C, Kiemle C, Dorninger M, Brousseau P (2012) Assimilation of water vapour airborne lidar observations: impact study on the COPS precipitation forecasts. Q J Roy Meteorol Soc 138:1652-1667

Brocard E, Philipona R, Haefele A, Romanens G, Mueller A, Ruffierux D, Simeonov V, Calpini B (2013) 2013: Raman Lidar for Meteorological Observations, RALMO - Part 2: validation of water vapor measurements. Atmos Meas Tech 6:1347-1358. https://doi.org/10.5194/amt-6-1347-2013

Brousseau P, Seity Y, Ricard D, Léger J (2016) Improvement of the forecast of convective activity from the AROME-France system. Q J R Meteorol Soc 142(699):2231-2243

Caumont O, Mandement M, Bouttier F, Eeckman J, Lebeaupin Brossier C, Lovat A, Nuissier O, Laurantin O (2021) The heavy precipitation event of 14-15 October 2018 in the Aude catchment: a meteorological study based on operational numerical weather prediction systems and standard and personal observations. Nat Hazards Earth Syst Sci 21:1135-1157

Chazette P, Dabas A, Sanak J, Lardier M, Royer P (2012) French airborne lidar measurements for Eyjafjallajökull ash plume survey. Atmos Chem Phys 12:7059-7072. https://doi.org/10.5194/acp-12-7059-2012

Chazette P, Marnas F, Totems J, Shang X (2014) Comparison of IASI water vapor retrieval with $\mathrm{H}_{2} \mathrm{O}$-Raman lidar in the framework of the Mediterranean HyMeX and ChArMEx programs. Atmos Chem Phys 14:9583-9596. https://doi.org/10.5194/acp-14-9583-2014

Chazette P, Flamant C, Raut J-C, Totems J, Shang X (2016a) Tropical moisture enriched storm tracks over the Mediterranean and their link with intense rainfall in the Cevennes-Vivarais area during HyMeX. Q J Roy Meteorol Soc 142(S1):320-334. https://doi.org/10.1002/qj.2674

Chazette P, Flamant C, Shang X, Totems J, Raut J-C, Doerenbecher A, Ducrocq V, Fourrié N, Bock O, Dorenbecher A, Cloché S (2016b) multi-instrument and multi-model assessment of atmospheric moisture variability over the Western Mediterranean during HyMeX. Q J R Meteorol Soc 142(S1):7-22. https://doi.org/10.1002/qj.2671

Chazette P, Totems J, Baron A, Flamant C, Bony S (2020) Trade-wind clouds and aerosols characterized by airborne horizontal lidar measurements during the EUREC ${ }^{4}$ A field campaign, Earth Syst. Sci. Data. Earth Syst Sci Data 12:2919-2936

Chazette P, Totems J, Shang X (2017) Atmospheric aerosol variability above the Paris Area during the 2015 heat wave - Comparison with the 2003 and 2006 heat waves. Atmos Environ 170. https://doi.org/10. 1016/j.atmosenv.2017.09.055

Chazette P, Totems J, Shang X (2019) Transport of aerosols over the French Riviera - link between groundbased lidar and spaceborne observations. Atmos Chem Phys 19:3885-3904. https://doi.org/10.5194/ acp-19-3885-2019

Chazette P, Flamant C, Sodemann H, Totems J, Monod A, Dieudonné E, Baron A, Seidl A, Steen-Larsen H-C, Doira P, Durand A, Ravier S (2021) The lacustrine-water vapor isotope inventory experiment L-WAIVE. Atmos Chem Phys 21:10911-10937

Desroziers G, Camino J-T, Berre L (2014) 4DEnVar: link with 4D state formulation of variational assimilation and different possible implementations. Q.J.R. Meteorol Soc 140:2097-2110. https://doi.org/10. 1002 /qj. 2325

Di Girolamo P, De Rosa B, Flamant C, Summa D, Bousquet O, Chazette P, Totems J, Cacciani M (2020) Water vapour mixing ratio and temperature intercomparison results in the framework of the 
hydrological cycle in the Mediterranean experiment - special observation period 1. Bull Atmos Sci Tech 1:133-153

Di Girolamo P, Cacciani M, Summa D, Scoccione A, De Rosa B, Behrendt A, Wulfmeyer V (2017) Characterisation of boundary layer turbulent processes by the Raman Lidar BASIL in the frame of HD(CP)2 observational prototype experiment. Atmos Chem Phys 17:745-767. https://doi.org/10.5194/ acp-17-745-2017

Di Girolamo P, Flamant C, Cacciani M, Richard E, Ducrocq V, Summa D, Stelitano D, Fourrié N, Said F (2016) Observation of low-level wind reversals over the Gulf of Lion and their impact on the water vapour variability. Q J R Meteorol Soc 142(S1):153-172. https://doi.org/10.1002/qj.2767

Di Girolamo P, Summa D, Sabatino D, Ferretti R, Faccani C (2009) Multiparameter Raman Lidar measurements for the characterization of a dry stratospheric intrusion event. J Atmos Oceanic Technol 26:1742-1762. https://doi.org/10.1175/2009JTECHA1253.1 (ISSN: 0739-0572)

Dinoev T, Simeonov VB, Arshinov Y, Bobrovnikov S, Ristori P, Calpini B, Parlange M, van den Bergh H (2013) Raman Lidar for meteorological observations, RALMO. Part 1: Instrument description. Atmos Meas Tech 6:1329-1346

Ducrocq V, Nuissier O, Ricard D, Lebeaupin C, Thouvenin T (2008) A numerical study of three catastrophic precipitating events over southern France. II: Mesoscale triggering and stationarity factors. Q J R Meteorol Soc 134:131-145. https://doi.org/10.1002/qj.199

Ducrocq V et al (2014) HyMeX-SOP1, the field campaign dedicated to heavy precipitation and flash flooding in the northwestern Mediterranean. Bull Am Meteo Soc 95:1083-1100

Duffourg F, Nuissier O, Ducrocq V, Flamant C, Chazette P, Delanoë J, Doerenbecher A, Fourrié N, Di Girolamo P, Lac C, Legain D, Martinet M, Saïd F, Bock O (2016) Offshore deep convection initiation and maintenance during HyMeX IOP 16a heavy precipitation event. Q J R Meteorol Soc 142(S1):259_ 274. https://doi.org/10.1002/qj.2725

Duffourg F, Lee K-O, Ducrocq V, Flamant C, Chazette P, Di Girolamo P (2018) Role of moisture patterns in the backbuilding formation of HyMeX IOP13 Heavy Precipitating Systems. Q J R Meteorol Soc 144:291-303

Duffourg F, Ducrocq V (2013) Assessment of the water supply to Mediterranean heavy precipitation : a method based on finely designed water budgets. Atmos Sci Lett 14(3):133-138

Fourrié N, Nuret M, Brousseau P, Caumont O (2021) Data assimilation impact studies with the AROMEWMED reanalysis of the first special observation period of the Hydrological cycle in the Mediterranean Experiment. Nat Hazards Earth Syst Sci 21:463-480. https://doi.org/10.5194/nhess-21-463-2021

Fourrié N, Nuret M, Brousseau P, Caumont O, Doerenbecher A, Wattrelot E, Moll P, Bénichou H, Puech D, Bock O, Bosser O, Chazette P, Flamant C, Di Girolamo P, Richard E, Saïd F (2019) The AROMEWMED reanalyses of the first special observation period of the hydrological cycle in the Mediterranean experiment. Geophys Model Dev 12:2657-2678

Fourrié N, Bresson É, Nuret M, Jany C, Brousseau P, Doerenbecher A, Kreitz M, Nuissier O, Sevault E, Bénichou H, Amodei M, Pouponneau F (2015) AROME-WMED, a real-time mesoscale model designed for the HyMeX special observation periods. Geosci Model Dev 8:1919-1941

Gaume E et al (2009) A compilation of data on European flash floods. J Hydrol 367:70-78

Grzeschik M, Bauer H-S, Wulfmeyer V, Engelbart D, Wandinger U, Mattis I, Althausen D, Engelmann R, Tesche M, Riede A (2008) Four dimensional variational data analysis of water vapor Raman lidar data and their impact on mesocale forecasts. J Atmos Ocean Technol 25:1437-1453

Goldsmith JE, Blair FH, Bisson SE, Turner DD (1998) Turn-key Raman lidar for profiling atmospheric water vapor, clouds, and aerosols. Appl Opt 37:4979-4990

Gustafsson N, Janjić T, Schraff C, Leuenberger D, Weissmann M, Reich H, Brousseau P, Montmerle T, Wattrelot E, Bučánek A, Mile M, Hamdi R, Lindskog M, Barkmeijer J, Dahlbom M, Macpherson B, Ballard S, Inverarity G, Carley J, Alexander C, Dowell D, Liu S, Ikuta Y, Fujita T (2018) Survey of data assimilation methods for convective-scale numerical weather prediction at operational centres. Q J R Meteorol Soc. https://doi.org/10.1002/qj.3179

Khodayar S, Czajka B, Caldas-Alvarez A, Helgert S, Flamant C, Di Girolamo P, Bock O, Chazette P (2018) Multi-scale observations of moisture feeding heavy precipitating systems in the Northwestern Mediterranean during HyMeX IOP12. Q J R Meteorol Soc 144:2761-2780

Kwon I-H, English S, Bell W, Potthast R, Collard A, Ruston B (2018) Assessment of progress and status of data assimilation in numerical weather prediction. Bull Amer Meteorol Soc 98:ES75-ES79

Lange D, Behrendt A, Wulfmeyer V (2019) Compact operational tropospheric water vapor and temperature Raman lidar with turbulence resolution. Geophys Res Lett 46:14844-14853. https://doi.org/10.1029/ 2019GL085774

Lenschow DH, Wulfmeyer V, Senff C (2000) Measuring second-through fourth-order moments in noisy data. J Atmos Oceanic Technol 17(10):1330-1347 
Leuenberger D, Haefele A, Omanovic N, Fengler M, Martucci G, Calpini B, Fuhrer O, Rossa A (2020) Improving high-impact numerical weather prediction with Lidar and drone observations. Bull Amer Meteorol Soc 101:1036-1051. https://doi.org/10.1175/BAMS-D-19-0119.1

Llasat C, Llasat-Botija M, Petrucci O, Pasqua AA, Rosselló J, Vinet F, Boissier L (2013) Towards a database on societal impact of Mediterranean floods within the framework of the HYMEX project. Nat Hazards Earth Syst Sci 13:1337-1350

Majumdar SJ (2016) A review of targeted observations. Bull Am Meteor Soc 97(12):2287-2303. https://doi. org/10.1175/bams-d-14-00259.1

Montmerle T, Michel Y, Arbogast E, Ménétrier B, Brousseau P (2018) A 3D ensemble variational data assimilation scheme for the limited-area AROME model: formulation and preliminary results. Q J R Meteorol Soc 144:2196-2215. https://doi.org/10.1002/qj.3334

Muñoz-Porcar C, Sicard M, Granados-Muñoz MJ, Barragán R, Comerón A, Rocadenbosh F, RodríguezGómez A, Garcia-Vizcaino D (2021) Synergy of Raman Lidar and modeled temperature for relative humidity profiling: assessment and uncertainty analysis. IEEE Trans Geosci Remote Sens 59:1-12

Muñoz-Porcar C, Comerón A, Sicard M, Barragán R, Garcia-Vizcaino D, Rodríguez-Gómez A, Rocadenbosh F, Granados-Muñoz MJ (2018) Calibration of Raman lidar water vapor mixing ratio measurements using zenithal measurements of diffuse sunlight and a radiative transfer model. IEEE Trans Geosci Remote Sens 56:7405-7414

Nuissier O, Ducrocq V, Ricard D, Lebeaupin C, Anquetin S (2008) A numerical study of three catastrophic precipitating events over southern France. I: Numerical framework and synoptic ingredients. Q J R Meteorol Soc 134:111-130. https://doi.org/10.1002/qj.200

Reichardt J, Wandinger U, Klein V, Mattis I, Hilber B, Begbie R (2012) RAMSES: German Meteorological Service autonomous Raman lidar for water vapor, temperature, aerosol, and cloud measurements. Appl Opt 51:8111-8131

Ribes A, Thao S, Vautard R, Dubuisson B, Somot S, Colin J, Planton S, Soubeyroux J-M (2019) Observed increase in extreme daily rainfall in the French Mediterranean. Clim Dyn 52:1095-1114. https://doi. org/10.1007/s00382-018-4179-2

Ricard DV, Ducrocq, and L. Auger, (2012) A climatology of the mesoscale environment associated with heavily precipitating events over a northwestern Mediterranean area. J Appl Meteor Climatol 51:468-488

Richard E, Fourrié N, Faivre M, Bielli S, Flamant C (2014) Assimilation of LEANDRE II water observations: impact study on the HyMeX SOP1 precipitation forecasts, 8th HyMeX workshop, Sep 2014. La Valletta, Malta, pp 15-18

Seity Y, Brousseau P, Malardel S, Hello G, Bénard P, Bouttier F, Lac C, Masson V (2011) The AROMEFrance convective scale operational model. Mon Weather Rev 139:976-991

Stelitano D, Di Girolamo P, Scoccione A, Summa D, Cacciani M (2019) Characterization of atmospheric aerosol optical properties based on the combined use of a ground-based Raman lidar and an airborne optical particle counter in the framework of the Hydrological Cycle in the Mediterranean Experiment - Special Observation Period 1. Atmos Meas Tech 12:2183-2199. https://doi.org/10.5194/amt-12-2183-2019

Stevens B, Bony S, Farrell D, Ament F, Blyth A, Fairall C, Karstensen J, Quinn P, Speich S, Aemisegger F, Albright AL, Bodenschatz E, Caesar K-A, Chewitt-Lucas R, Delanoë J, De Boer G, Ewald F, Forde M, George G, Hausold A, Hagen M, Hirsch L, Jansen F, Kinne S, Klocke D, Kölling T, Konow H, Mohr W, Naumann AK, Nuijens L, Pincus R, Reverdin G, Roberts G, Schnitt S, Sullivan P, Touzé-Peiffer L, Vial J, Vogel R, Acquistapace C, Alexander N, Alves L, Arixi S, Asmath H, Bagheri G, Bailey A, Baranowski D, Baron A, Barrau S, Barrett PA, Behrendt A, Bellenger H, Bendinger A, Beucher F, Bigorre S, Blossey P, Bock O, Bosser P, Bourras D, Bouruet-Aubertot P, Bower K, Branger H, Brennek M, Brewer A, Brilouet P-E, Brügmann B, Buehler SA, Burke E, Burton R, Böing S, Calmer R, Canonici J-C, Carton X, Cato GJ, Charles JA, Chazette P, Chen Y, Choularton T, Chuang P, Clarke S, Coe H, Cornet C, Coutris P, Couvreux F, Crewell S, Cronin T, Cui Z, Cuypers Y, Daley A, Damerell GM, Dauhut T, De Graaf D, De Groot G, De Szoeke SP, Denby L, Deneke H, Desbios J-P, Douet V, Drushka K, Dütsch M, Ehrlich A, Emanuel K, Emmanouilidis A, Etienne J-C, Etienne-Leblanc S, Faure G, Feingold G, Ferrero L, Fildier B, Fix A, Flamant C, Flatau PJ, Foltz GR, Forster L, Gadian A, Galewsky J, Gallagher M, Gallimore P, Gaston C, Gentemann C, Geyskens N, Giez A, Gourbeyre C, Gross S, Grosz R, Gutleben M, Güttler J, Hall K, Harris G, Helfer KC, Henze D, Herbert C, Heywood KJ, Holanda B, IbanezLandeta A, Intrieri J, Iyer S, Jacob M, Julien F, Kalesse H, Kazil J, Kellman A, Kirchner U, Klingebiel M, Kremper LA, Kretzschmar J, Krüger O, Kurz A, Körner M, L'Hégaret P, Lachlan-Cope T, Laing A, Landschützer P, Lang T, Lange D, Lange I, Laplace C, Laxenaire R, Le Bihan C, Leandro M, Lefevre N, Lenschow D, Li Q, Lloyd G, Los S, Losi N, Lothon M, Lovell O, Luneau C, Makuch P, Malinowski S, Manta G, Marinou E, Marsden N, Matthieu L, Maury N, Mayer B, Mayers-Als M, Mazel C, McGeary W, McWilliams JC, Mech M, Mehlmann M, Meroni AN, Mieslinger T, Minikin A, Morfa Avalos Y, 
Muller C, Musat I, Möller G, Napoli A, Neuberger A, Noone D, Nordsiek F, Nowak JL, Olivier L, Oswald L, Parker DJ, Peck C, Person R, Plueddemann A, Pologne L, Posyniak M, Prange M, Pöhlker M, Pöhlker C, Pörtge V, Pöschl U, Quiñones Meléndez E, Radtke J, Ramage K, Reimann J, Renault L, Reus K, Reyes A, Ribbe J, Ringel M, Ritschel M, Rocha CB, Rochetin N, Rollo C, Röttenbacher J, Saffin L, Sandiford S, Sandu I, Schemann V, Schirmacher I, Schlenczek O, Schmidt J, Schröder M, Schulz H, Schwarzenboeck A, Schäfer M, Sealy A, Serikov I, Shohan S, Siddle E, Siebesma AP, Späth F, Stephan CC, Stolla MK, Szkółka W, Tarot S, Tetoni E, Thompson E, Thomson J, Tomassini L, Totems J, Villiger L, Walther A, Webber B, Wendisch M, Whitehall S, Wiltshire A, Wing AA, Wirth M, Wiskand J, Wolf K, Worbes L, Wright E, Wulfmeyer V, Young S, Zhang D, Zhang C, Ziemen F, Zinner T, Zuidema P, Zöger M (2021) EUREC4A. Earth Syst Sci Data. https://doi.org/10.5194/essd-2021-18

Thundathil R, Schwitalla T, Behrendt A, Muppa SK, Adam S, Wulfmeyer V (2020) Assimilation of lidar water vapour mixing ratio and temperature profiles into a convection-permitting model. J Meteorol Soc Jpn 98:959-986

Totems J, Chazette P, Raut J-C, J. (2019) Accuracy of current Arctic springtime water vapour estimates, assessed by Raman lidar. Q J R Meteorol Soc 145(720):1234-1249. https://doi.org/10.1002/qj.3492

Weckwerth T, Parsons D, Koch S, Moore J, Lemone P, Demoz B, Flamant C, Geerts B, Wang J, Feltz W (2004) An overview of the International H2O Project (IHOP_2002) and some preliminary highlights. Bull Amer Meteorol Soc 85:253-277

Wulfmeyer V, Hardesty RM, Turner DD, Behrendt A, Cadeddu MP, Di Girolamo P, Schlüssel P, Van Baelen J, Zus F (2015) A review of the remote sensing of lower tropospheric thermodynamic profiles and its indispensable role for the understanding and the simulation of water and energy cycles. Rev Geophys 53:819-895

Wulfmeyer V, Bauer H-S, Grzeschik M, Behrendt A, Vandenberghe F, Browell EV, Ismail S, Ferrare RA (2006) Four-dimensional variational assimilation of water vapor differential absorption lidar data: the first case study within IHOP-2002. Mon Weather Rev 134:209-230

Yoshida S, Yokota S, Seko H, Sakai T, Nagai T (2020) Observation system simulation experiments of water vapor profiles observed by Raman lidar using LETKF system. SOLA 16:43-50. https://doi.org/10. 2151/sola.2020-008

Publisher's note Springer Nature remains neutral with regard to jurisdictional claims in published maps and institutional affiliations.

\section{Authors and Affiliations}

Cyrille Flamant $^{1}$ D $\cdot$ Patrick Chazette ${ }^{2}$. Olivier Caumont ${ }^{3} \cdot$ Paolo Di Girolamo $^{4}$. Andreas Behrendt ${ }^{5} \cdot$ Michaël Sicard $^{6,7}$. Julien Totems ${ }^{2} \cdot$ Diego Lange $^{5}$. Nadia Fourrié ${ }^{3}$. Pierre Brousseau ${ }^{3}$. Clotilde Augros ${ }^{3}$. Alexandre Baron ${ }^{2}$. Marco Cacciani ${ }^{4} \cdot$ Adolfo Comerón $^{6}$ - Benedetto De Rosa ${ }^{4} \cdot$ Veronique Ducrocq $^{3}$. Pascal Genau ${ }^{1}$. Laurent Labatut ${ }^{3}$. Constantino Muñoz-Porcar ${ }^{6}$. Alejandro Rodríguez-Gómez ${ }^{6} \cdot$ Donato Summa $^{4,8} \cdot$ Rohith Thundathil $^{5}$. Volker Wulfmeyer ${ }^{5}$

1 LATMOS/IPSL, CNRS-SU-UVSQ, Sorbonne Université, Paris, France

2 LSCE/IPSL, CNRS-CEA-UVSQ, University Paris-Saclay, CEA Saclay, Gif sur Yvette, France

3 CNRM, Université de Toulouse, Météo-France, CNRS, Toulouse, France

4 Scuola Di Ingegneria, Università Della Basilicata, Potenza, Italy

5 Institut Für Physik Und Meteorologie, Universitat Hohenheim, Stuttgart, Germany

6 CommSensLab, Department of Signal Theory and Communications, Universitat Politècnica de Catalunya, Barcelona, Spain

7 Institut D'Estudis Espacials de Catalunya, Ciències I Tecnologies de L'Espai-Centre de Recerca de L'Aeronàutica I de L'Espai, Universitat Politècnica de Catalunya (UPC), 08034 Barcelona, Spain

8 CNR-IMAA, Tito Scalo center, Potenza, Italy 